\title{
Why Warner-Lieberman Failed and How to Get America's Working Families behind the Next Cap-and-Trade Bill \\ By David Wheeler
}

Abstract
Among partisans of greenhouse gas emissions regulation, the Senate's failure to pass
the Warner-Lieberman cap-and-trade bill is often attributed to rampant denial, fueled
by diehard political conservatism, energy-company propaganda, and government
suppression of evidence on global warming. If so, the solution to the problem is
electoral change, exposure of the propaganda, and public education. However,
public concern is already so widespread that even leaders of the Southern Baptist
Convention have acknowledged the need for action. In this paper, I consider two
additional forces that have stymied carbon emissions regulation in developing
countries. The first is the perception that costly carbon regulation promoted by the
rich will inflict an unjust burden on the poor. The second is hostility to taxation of
critical fossil-fuel resources that were developed long before climate risk was
identified. My econometric analysis suggests that these same forces have
significantly affected senators' votes on Warner-Lieberman. By implication,
Congress is not likely to approve cap-and-trade legislation unless Americans with
below-median incomes are compensated for expected losses. My analysis supports
recent proposals for direct distribution of emissions permit auction revenues to
American families on an equal per-capita basis.
.

The Center for Global Development is an independent, nonprofit policy research organization that is dedicated to reducing global poverty and inequality and to making globalization work for the poor

Use and dissemination of this Working Paper is encouraged; however, reproduced copies may not be used for commercial purposes. Further usage is permitted under the terms of the Creative Commons License. The views expressed in this paper are those of the author and should not be attributed to the board of directors or funders of the Center for Global Development.

www.cgdev.org 


\title{
Why Warner-Lieberman Failed and How to Get America's Working Families behind the Next Cap-and-Trade Bill
}

\author{
David Wheeler \\ Center for Global Development \\ July 2008
}

This paper is dedicated to the people of West Virginia and Alabama, my parents' home states. We won't solve the climate problem without them. For valuable comments and suggestions, many thanks to Nancy Birdsall, Bill Cline, Richard Cooper, Robin Kraft, Lawrence MacDonald, Joel Meister, Darius Nassiry, Brad Parks, Vijaya Ramachandran, Kevin Ummel and Dave Witzel. All remaining errors are my own. 


\section{Introduction}

The climate crisis is mounting, but America is at a standstill. On June 6, 2008, domestic cap-and-trade legislation was declared dead for this term when the WarnerLieberman bill failed a critical cloture vote in the Senate. ${ }^{1}$ Even if the next President supports carbon regulation, he will be hard-pressed to ensure Congressional passage before the US delegation goes to the Copenhagen climate-change negotiations eleven months after Inauguration Day. Without binding regulation in the US, developingcountries will simply refuse to accept any limitation on carbon emissions. In summary, we are still headed straight for a climate crisis and the failure of WarnerLieberman is potentially tragic.

How did this happen? Partisans of greenhouse emissions regulation frequently cite rampant denial, fueled by diehard political conservatism, energy-company propaganda, and government suppression of evidence on global warming (Gore, 2007). In this view, the solution to the problem is electoral change, exposure of the propaganda, and public education. While there is undoubtedly some truth in these propositions, they fail to acknowledge the rapid deepening of concern about climate change - so rapid, in fact, that even leaders of the Southern Baptist Convention have recently acknowledged the threat and the need to act (Banerjee, 2008).

\footnotetext{
1 The Democrats introduced a cloture vote, attempting to prevent a Republican filibuster of the proposed legislation. The US Senate defines the cloture rule as follows: "The only procedure by which the Senate can vote to place a time limit on consideration of a bill or other matter, and thereby overcome a filibuster. Under the cloture rule (Rule XXII), the Senate may limit consideration of a pending matter to 30 additional hours, but only by vote of three-fifths of the full Senate, normally 60 votes." (http://www.senate.gov/reference/glossary term/cloture.htm). The cloture vote record is available from the U.S. Senate at http://www.senate.gov/legislative/LIS/roll_call_lists/roll_call_vote_cfm.cfm?congress $=110 \&$ session=2 $\underline{\text { vote }}=00145$ \#state
} 
In this paper, I look elsewhere for plausible explanations. Specifically, I consider two forces that have stymied carbon emissions regulation in developing countries. The first is a perceived climate of injustice, in which carbon regulation promoted by the rich will inflict a disproportionate burden on poor regions that are not responsible for the problem and least able to bear the cost of solving it (Roberts and Parks, 2006), The second, in regions with heavy fossil-fuel dependence, is hostility to taxation of critical resources that were developed long before climate risk was identified. This paper uses an econometric analysis of the June 6 cloture vote to test the impacts of the same two forces on proposed carbon regulation in the US.

The remainder of the paper is organized as follows. In Section 2, I examine variations in income and fossil-fuel dependency across US senators' home states, along with the degree of conservatism in their voting records. Section 3 estimates the relationship between these variables and senators' votes on the cloture motion of June 6, with additional controls for party affiliation, gender, campaign contributions from the energy sector, and an index of state-level climate threats. In addition, Section 3 uses two simulation exercises to assess the independent impacts of states' income, fossil-fuel dependency and conservatism. In Section 4 I discuss the implications for legislative design, while Section 5 provides a summary and conclusions.

\section{American Diversity and Its Implications}

Although students of economic development stress the importance of absolute inequality, a broad literature also documents the political importance of relative inequality. Wounded perceptions of fairness can undermine policy reform when it threatens to impose a costly, uniform burden on people whose coping resources are 
very different (Henrich, et al., 2006; Maslach and Leiter, 2008). Cap-and-trade regulation provides an example, because it will significantly raise the cost of fossil energy. Poor families spend a much higher portion of their incomes on energy than rich families (IEA, 2008; Table 10 in this paper), and some regions of the US are much more dependent on fossil energy sources than others. At the same time, of course, many Americans are hostile to government regulation on political or philosophical grounds.

Table 1 illustrates American diversity in income, fossil energy dependence and political conservatism. States' per capita incomes in 2007 varied from $\$ 28,846$ to $\$ 54,117$; their fossil-fuel dependency in the power sector from $0 \%$ to $98.5 \%$; and their senators' conservatism ratings from 0 to 100 on a scale developed by the American Conservative Union. In light of my previous discussion, cap-and-trade legislation seems likely to face more resistance from states that are poorer and more dependent on fossil fuels, as well as those which lean toward political conservatism.

I analyze the effects of these factors on the Warner-Lieberman cloture vote, which failed to override a threatened filibuster by opponents of the bill. The data seem appropriate for statistical tests because senators' cloture votes were not constrained by individual factors. Table 2 displays minimum and maximum values by vote for all three variables. For fossil-fuel dependency, both yes and no votes span the range from very small percentages to nearly 100 percent. Conservative ratings demonstrate a similar range, with minimum values of 0 for yes and no votes and values above 90 for both votes. Income ranges are also very broad, with nearlyidentical minimum incomes for both votes and a maximum value of $\$ 43,226$ for no 
votes cast by the senators from Wyoming, which ranks sixth in income among American states (after Connecticut, New Jersey, Massachusetts, New York and Maryland). Under these conditions, statistical analysis can credibly test for independent effects.

\section{Econometric Estimation}

\subsection{Data}

I draw state-level indicators of income, fossil-fuel dependency and political conservatism from the sources cited in Table $1 .^{2}$ I also allow for the possible effects of party affiliation, gender, campaign contributions from the energy sector, and an index of state-level climate threats. Party affiliation figures prominently in press accounts of the cloture vote, so it would be plausible to assert a significant role for partisan voting. I test this proposition with a dummy variable for Republican Party membership. Senators' votes may also be influenced by campaign contributions from vested interests. I test this by introducing controls for campaign contributions to each senator during the 2006 and 2008 electoral cycles, from contributors in five energyrelated sectors identified by the Center for Responsive Politics (CRP, 2008): electric utilities, oil and gas, coal mining, transportation and transport unions. Sectoral diversity makes some of these categories problematic. For example, electric utilities include low-carbon energy firms (e.g. providers of nuclear, hydro and renewable energy) whose relative market position would improve in a cap-and-trade regime. I therefore test the effects of contributions from individual energy-related sectors, as well as total contributions from these sectors. I also consider energy-sector

\footnotetext{
2 The full dataset is included in Appendix B.
} 
contributions relative to a senator's total contributions. This allows for the potential importance of small energy-related contributions for senators whose total contributions are also small.

I also test the impact of perceived climate threats on senators' support for Warner-Lieberman. To construct a threat index, I draw on state-level information about climate disasters and emergencies declared by the Federal Emergency Management Agency (FEMA, 2008). I limit the sample to the past five years, the period in which public awareness of climate change has rapidly increased. ${ }^{3}$ Any index of perceived threat is problematic, because no consistently-measured damage estimates are available for all relevant categories. I test three variants on FEMAdeclared disasters and emergencies for individual states: total counts for five categories -- floods, rain storms (including tornadoes), hurricanes, droughts and fires; separate category counts for composite floods and storms (which are often reported together), hurricanes and fires; and counts divided by state areas. The latter measure seems plausible from a technical standpoint (larger states will have more disaster events, other things equal), but less so from a political standpoint (senators from larger states will get more calls from climate-affected constituents, but they may not take individual calls less seriously than their colleagues from smaller states).

I specify the following probability model to assess the importance of these factors in determining the June 6 cloture vote:

3 Significant events in this context include Hurricane Katrina (2005); the widely-publicized climate change lectures of Vice President Al Gore, culminating in the film "An Inconvenient Truth" (2006); and publication of the Fourth Assessment Report of the Intergovernmental Panel on Climate Change (2007 - http://www.ipcc.ch/). 
(1) $p(\text { Yes })_{i j}=\beta_{0}+\beta_{1} Y_{j}+\beta_{2} F_{j}+\beta_{3} C_{i j}+\beta_{4} R_{i j}+\beta_{5} G_{i j}+\beta_{6} P_{i j}+\beta_{7} D_{j}+\varepsilon_{i}$

Where:

$\mathrm{Yes}_{\mathrm{ij}}=$ Yes vote on cloture (pro-cap-and-trade) by senator $\mathrm{i}$ from state $\mathrm{j}$

$\mathrm{Y}_{\mathrm{j}} \quad=$ Per capita income in state $\mathrm{j}$ (2007)

$\mathrm{F}_{\mathrm{j}} \quad$ = Fraction of power provided by fossil fuels in state $\mathrm{j}$ (2007)

$\mathrm{C}_{\mathrm{ij}}=$ American Conservative Union rating of senator i from state $\mathrm{j}(2007)^{4}$

$\mathrm{R}_{\mathrm{ij}}=$ Party affiliation of senator $\mathrm{i}$ from state $\mathrm{j}(1=$ Republican)

$\mathrm{G}_{\mathrm{ij}}=$ Gender of senator $\mathrm{i}$ from state $\mathrm{j}(1=$ female $)$

$\mathrm{P}_{\mathrm{ij}} \quad$ = Energy-sector campaign contributions to senator $\mathrm{i}$ from state $\mathrm{j}$ (2006-2008)

$\mathrm{D}_{\mathrm{j}} \quad$ =FEMA-declared climate disasters and emergencies in state $\mathrm{j}$ (2004-2008)

$\varepsilon_{\mathrm{j}} \quad=$ A random error term

Predicted effects are $\beta_{1}>0, \beta_{2}<0, \beta_{3}<0, \beta_{4}<0, \beta_{6}<0, \beta_{7}>0$ : The probability of a yes vote should increase with the per capita income of the senator's state and the number of FEMA-declared climate disasters and emergencies. It should decrease with the fraction of power provided by fossil fuels and a senator's conservative rating, Republican party status and energy-sector campaign contributions. I have no prior prediction for the effect of gender.

\subsection{Model Estimation}

I estimate the model by probit for voting senators, predict the yes-vote probabilities, translate these to 1-0 outcomes using a threshold probability of 0.6 , and evaluate the prediction accuracy of the model. ${ }^{5}$

Table 3 reports results for the core regression (column (1) - income, fossil fuel dependency and conservative rating), as well as selected experiments with the other variables. The estimated coefficients for income per capita, fossil fuel dependency and conservative rating all have the expected signs, and all are significant at the 5\% or $1 \%$ level. After controlling for these variables, I find no significant effects in any

\footnotetext{
${ }^{4}$ Senator Wicker of Mississippi does not yet have an ACU rating, so I have used the average rating for Senator Cochran and Senator Lott, Senator Wicker's predecessor.

${ }_{5}$ Probit estimation techniques constrain predicted probabilities to the range 0-1.
} 
regression for party affiliation, gender, campaign contributions or climate disasters. The three core variables, on the other hand, retain their significance and impact magnitudes in all the regressions. Experiments with interactions and alternative functional forms for the three core variables did not yield improvements in the regression fit.

\subsection{Vote Predictions}

Using the core regression results in Table 3, column (1) I translate the predicted probabilities into discrete predictions using a conservative rule that assigns a yes vote to probabilities greater than or equal to 0.6 . I present detailed results for correctlypredicted votes in Appendix A. As Table 4 shows, the model predicts senators' votes with $92.9 \%$ accuracy ( 6 predicted votes in 84 are incorrect). Table 5 tabulates the incorrect votes. Notable outliers among the yes votes are Senators Dole of North Carolina $(\mathrm{p}(\mathrm{yes})=.062)$ and Martinez of Florida $(.211)$; outliers among the no votes are Senators Johnson of South Dakota $(\mathrm{p}(\mathrm{yes})=.979)$ and Brown of Ohio (.873).

The prediction results suggest that the yes-no vote split would have been 55-45 if all senators had voted. ${ }^{6}$ Table 6 presents predicted probabilities and votes for the 16 Senators who were missing. As predicted by the model, Senators Obama and Clinton have since stated that they would have voted yes (Eilperin, 2008). Senator McCain has also stated that he would have voted yes on cloture, despite his very small prediction probability $(0.12)$. Some question remains, since he added that he would have opposed the bill on nuclear-related issues. However, McCain's strong

\footnotetext{
${ }^{6}$ This is extremely close to the full result (54 - 46) suggested by a related Washington Post story (Eilperin, 2008). However, the story relies on statements by senators who did not have to reveal their votes, while the model's prediction is based on actual behavior and its determinants. For the full set of correct predictions, see Appendix A.
} 
support for climate change legislation suggests that he would probably have voted yes.

\subsection{Simulation Experiments}

To assess the independent effects of the three core variables, I conduct simulation experiments with all combinations of minimum, median and maximum sample values of state per-capita incomes, fossil fuel dependencies and conservatism ratings. Using the probit results in Table 3, column (1) I simulate a hypothetical senator's yes-vote probability in each of the 27 cases. Table 7 reports the full results, which indicate large impacts for all three variables. To illustrate the impact of conservatism, the table's first three rows predict yes-vote probabilities for a hypothetical senator with varying degrees of conservatism in a poor state with zero dependence on fossil power. For the maximum conservative rating (100), the model predicts a .16 probability of voting yes. When the conservative rating drops to the Senate's median (30), however, the yes-vote probability jumps to .92 .

For the same hypothetical senator from the same poor state, variations in fossil fuel dependency also have powerful effects. To see this, hold the conservative rating constant at its median value of 30 and vary fossil fuel dependency from the minimum of 0 (row 1$)$, to the national median (.69 - row 5) and the national maximum (.98 row 8). Holding the state's income and the senator's conservatism constant, these changes decrease the probability of a yes vote from .92 to .41 , and then to .17 .

Table 8 focuses on the impact of income, since it is particularly important for this analysis. The table reports the distribution of simulation results as state percapita income shifts from the US minimum $(\$ 29,000)$ to the median $(\$ 36,000)$ and 
the maximum $(\$ 54,000)$. Each table row summarizes results for all combinations of fossil-fuel dependencies (min-median-max) and conservative ratings (min-medianmax). The powerful impact of income is evident in the results. For the lowest state income, variations in fossil fuel dependency and conservatism generate a range of voting probabilities from 0 to .99 , with a median probability of .41 . Shifting to the median state income leaves the minimum yes-vote probability basically unchanged, but the rest of the distribution shifts sharply upward. The lower-quartile yes-vote probability is now .49 , the median .76 and the third quartile .96 . Finally, a shift to the maximum income has a radical effect on the entire distribution. Now the minimum probability of a yes vote is .53 , and the other quartile points are .99 or higher.

These income results support the proposition that aversion to the regressive cost burden of Warner-Lieberman is a powerful deterrent to a yes vote by senators from poor states. In another experiment, I progressively equalize state incomes and tabulate the predicted effect on senators' votes. In this experiment, I raise the income floor for American states in increments of $\$ 5,000$. As the floor rises, no state falls below it but incomes in states above it are unaffected. Both fossil fuel dependency and the conservative rating remain the same for each senator. Table 9 reports the results, starting with the predicted votes of 100 senators at current state per capita income, fossil fuel dependency, and the senator's conservative rating. The current distribution of votes (counting predictions for 16 senators who did not vote on June 6) is 55 yes -45 no. Raising the income floor by $\$ 5,000$ shifts the vote to $57-43$; another $\$ 5,000$ increase is sufficient to achieve cloture (60-40); another $\$ 5,000$ 
ensures a veto-proof majority (68-32); and additional increases to the current maximum income raise the majority to $93-7$ and 100-0.

\section{Implications of the Results}

My results suggest strong, independent impacts of income and fossil fuel dependency on cloture votes, regardless of senators' relative conservatism on other issues. The results support the hypothesis that the votes of senators from states that are relatively poor and dependent on fossil fuels are strongly affected by their constituents' aversion to the differential costs imposed by a cap-and-trade system.

The political implication is clear: Serious cap-and-trade regulation is unlikely to pass the Senate without explicit compensation for differential costs. This is particularly true now, since escalating fossil fuel prices have already increased the burden on families with below-median incomes (everywhere for transport, and particularly in states whose power sectors are more fossil-dependent). The most straightforward measure, recently proposed by Robert Reich, would be a direct rebate from cap-and-trade auction revenues to American families on a per-capita basis (Reich, 2008). ${ }^{7}$ Recently, the US Energy Information Agency has estimated that a $100 \%$ auction of emissions credits under Warner-Lieberman would yield about $\$ 150$ billion/year by 2020 (EIA, 2008). Divided equally among 300 million Americans, this would provide an annual payment of $\$ 500$ per person, or $\$ 2,000$ for a family of four.

Table 10 provides data on 2001 energy and fuel expenditures for families in three ranges below the US median family income: $\$ 0-\$ 9,999, \$ 10,000-\$ 29,999$ and

\footnotetext{
${ }^{7}$ For an equivalent global proposal, see Barnes, et al. (2008).
} 
$\$ 30,000-\$ 49,999$ (EIA 2001, 2005). ${ }^{8}$ Their energy and fuel expenditures by group were $\$ 1,878, \$ 2,306$ and $\$ 3,022$, or $37.6 \%, 11.5 \%$ and $7.6 \%$ of total income, respectively. ${ }^{9}$ According to the EIA's assessment, enactment of Warner-Lieberman would raise total energy and fuel expenditures by $7 \%$ to $24 \%$ in all three income groups. However, enactment of cap-and-trade with auction payments of $\$ 2,000$ to families in these groups would actually increase their incomes, even after subtracting the extra energy and fuel costs. I calculate the following percent increases in household income: $30.9-37.5 \%$ (\$0-\$9,999); 7.2-9.2\% (\$10,000-\$29,999); 3.2-4.5\% $(\$ 30,000-\$ 49,999)$. I conclude that distributing all auction proceeds to American families would result in a significant income increase for families with incomes of $\$ 50,000$ or less. ${ }^{10}$ Even a distribution of $30 \%$ of the proceeds would leave their total incomes unchanged, while emissions reduction would be promoted by the increased prices of carbon-intensive energy and fuels relative to the prices of other goods. This would align households with the overall emissions reduction goal, which would be enforced by a mandated decline in the national emissions cap over time.

The program would probably have more popular appeal if claims on auction revenues were represented by share certificates that would be issued to individuals on request, or held in trust by a public corporation chartered to manage the funds. Appendix C provides an illustrative Certified Atmospheric Share (CASH) certificate payable from United States Carbon Account Proceeds (USCAP). The CASH

${ }^{8}$ According to the US Department of Housing and Urban Development, the US median family income in FY 2008 is $\$ 61,500$ (http://www.huduser.org/datasets/il/i108/Medians_2008.pdf).

9 This calculation uses interval midpoint incomes: $\$ 5,000, \$ 20,000, \$ 40,000$.

10 These results are corroborated by a recent Congressional Budget Office study. For details, see CBO (2008). 
certificate represents the automatic claim on auction revenue by an individual US citizen, paid into the individual's specified account by the Internal Revenue Service. This illustration assumes that permits are auctioned annually, with revenues divided equally among US citizens. CASH certificates (and the associated payment claims) could be tradable, enabling families to realize the capitalized value of expected future payments if they chose to do so. The registered sale of a CASH certificate would automatically transfer its annual payment stream to the buyer. Assuming a competitive risk-free interest rate of 5\%, a CASH certificate with expected future payments of $\$ 500$ each year could be sold for $\$ 10,000$, and ownership of CASH certificates would add $\$ 40,000$ to the liquid assets of a fourperson family.

\section{Summary and Conclusions}

In this paper, I have used econometric analysis to assess senators' support for the Warner-Lieberman cap-and-trade bill as a function of their conservative ratings, and their states' per capita incomes and degrees of fossil-fuel dependency. My results include three findings of particular interest. First, each of the three factors varies across most of its full range, regardless of the values of the other two. This establishes a credible foundation for statistical experiments under the assumption of independent variation. Second, all three variables are determinants of senators' votes at high levels of statistical significance. This finding is robust to the inclusion of controls for party affiliation, gender, energy-sector campaign contributions and state-level climate disasters. Third, each of the variables has a very powerful, independent effect. 
Holding any two variables constant, within-sample variation in the third is generally sufficient to move the probability of a yes vote between very low and very high.

The impact is particularly striking for income, with great significance for the topic of this paper. As the June 6 cloture vote revealed, the Senate cannot achieve filibuster-proof support for cap-and-trade legislation under current conditions. Undoubtedly, the recent sharp increase in fossil fuel prices has aggravated the situation. Neither fossil-fuel dependency nor senators' innate conservativism is likely to change much in the near term (although a few conservative senators may lose to liberals in the fall election), so there is no reason to hope that these variables will propel a significant change in the voting pattern.

Income, however, is another matter. My results suggest that poor states' aversion to a differential cost burden has significantly weakened support for WarnerLieberman. However, my results also suggest that more senators from states with below-median incomes will support Warner-Lieberman, regardless of their conservatism or their states' fossil-fuel dependency, if direct payments from emissions permit auctions make below-median households better off. Assuming that permits are fully auctioned, break-even for below-median families appears to require direct payments of $30 \%$ of total auction revenues. This could be doubled to ensure support, however, while still leaving a vast sum ( $\$ 60$ billion/year for an annual $\$ 150$ billion auction) to compensate displaced US workers (particularly coal miners and processors) and promote investment in clean technology. The direct payment system could be vested in a trust fund that is separate from standard government accounts, and distribution could be delegated to the Internal Revenue Service. This would be 
no more difficult than the administration's current $\$ 600$ distribution to individuals for macroeconomic stimulus.

The direct-payment system would not have much effect on the overall distribution of income, but it would have a powerful effect on the margin where household energy expenditures are determined. Simply allocating a large share of the permit auction proceeds on an equal basis to all Americans will actually turn a large profit for poorer Americans, even after the impact of Warner-Lieberman on energy and fuel costs is taken into account. This will make many below-median Americans absolutely better off and - a critical factor for perceptions of fairness - better off relative to more affluent Americans as well. My econometric and simulation results for income strongly suggest that these payments will shift the votes of many senators whose conservatism and states' fossil dependency would otherwise keep them from supporting Warner Lieberman. Given the urgency of the climate problem, Congress should consider such a direct payment system as soon as possible. 


\section{References}

Barnes, Peter, Robert Costanza, Paul Hawken, David Orr, Elinor Ostrom, Alvaro Umaña and Oran Young. 2008. Creating an Earth Atmospheric Trust: A system to control climate change and reduce poverty. January. Available online at http://gristmill.grist.org/print/2008/1/2/114337/5638? show comments=no.

Banerjee, Neela. 2008. "Southern Baptists Back a Shift on Climate Change." New York Times. March 10. Available online at http://www.nytimes.com/2008/03/10/us/10baptist.html? r=1\&oref=slogin\&pagewant ed=print.

Center for Responsive Politics (CRP). 2008. Information on sector and company contributions to individual senators available online at http://www.opensecrets.org/politicians/index.php

Congressional Budget Office (CBO). 2008. Options for Offsetting the Economic Impact on Low- and Moderate-Income Households of a Cap-and-Trade Program for Carbon Dioxide Emissions. June 17. Available online at http://www.cbo.gov/ftpdocs/93xx/doc9319/06-17-ClimateChangeCosts.pdf

Eilperin, Juliet. 2008. "Senate Leaders Pull Measure on Climate: Democrats Lacked Votes to End Filibuster." Washington Post. Saturday, June 7; A03. Available online at http://www.washingtonpost.com/wpdyn/content/article/2008/06/06/AR2008060600333 pf.html.

Federal Emergency Management Agency (FEMA). 2008. Declared Disasters by Year or State. Data for 2004-2008. Available online at http://www.fema.gov/news/disaster totals annual.fema

Gore, Al. 2007. The Assault on Reason. New York: Penguin.

Henrich, Joseph, Richard McElreath, Abigail Barr, Jean Ensminger, Clark Barrett, Alexander Bolyanatz, Juan Camilo Cardenas, Michael Gurven, Edwins Gwako, Natalie Henrich, Carolyn Lesorogol, Frank Marlowe, David Tracer, and John Ziker. 2006. "Costly Punishment Across Human Societies." Science. Vol. 312(23) 17671770. Available online at http://www.psych.ubc.ca/ henrich/Website/Papers/Science/Henrichetal2006Science.p df.

Maslach, Christina and Michael Leiter. 2008. "Early predictors of job burnout and engagement." Journal of Applied Psychology. May Vol 93(3) 498-512. Available online at http://psycnet.apa.org/index.cfm?fa $=$ search.displayRecord\&uid $=2008$ $\underline{05281-002 .}$. 
Roberts, J. Timmons, and Bradley Parks. 2006. A Climate of Injustice:

Global Inequality, North-South Politics, and Climate Policy. Cambridge: MIT Press.

Reich, Robert. 2008. “How About a Cap-and-Trade Dividend?” Wall Street Journal. June 4; A21. Available online at http://online.wsj.com/article/SB121253738014643227.html?mod=googlenews wsj.

US Energy Information Administration (EIA). 2008. Energy Market and Economic Impacts of S. 2191, the Lieberman-Warner Climate Security Act of 2007. Report \#: SR-OIAF/2008-01. April. Executive summary available online at http://www.eia.doe.gov/oiaf/servicerpt/s2191/execsummary.html. Summary spreadsheet available online at http://www.eia.doe.gov/oiaf/servicerpt/s2191/excel/s2191.xls.

US Energy Information Administration (EIA). 2005. Household Vehicles Energy Use: Latest Data \& Trends. November. Table A2. Available online at http://www.eia.doe.gov/emeu/rtecs/nhts survey/2001/tablefiles/page a02.html

US Energy Information Administration (EIA). 2001. Residential Energy Consumption Survey. Available online at http://www.eia.doe.gov/emeu/recs/recs2001/detailcetbls.html 
Table 1: State-Level Indicators of Income, Fossil-Fuel

Dependency and Conservatism

\begin{tabular}{|l|c|c|c|}
\hline & \multicolumn{3}{|c|}{ State-Level Indicators, 2007 } \\
\hline & $\begin{array}{c}\text { Income } \\
\text { Per } \\
\text { Capita }^{\text {a }}\end{array}$ & $\begin{array}{c}\text { Fossil-Fuel } \\
\text { Fraction of }^{\text {Power }}\end{array}$ & $\begin{array}{c}\text { Senator's } \\
\text { Conservative } \\
\text { Rating }^{c}\end{array}$ \\
\hline Minimum & $\$ 28,845$ & 0.0076 & 0 \\
\hline Quartile 1 & $\$ 33,457$ & 0.5264 & 4 \\
\hline Median & $\$ 35,567$ & 0.6872 & 30 \\
\hline Quartile 3 & $\$ 40,480$ & 0.8057 & 84 \\
\hline Maximum & $\$ 54,117$ & 0.9845 & 100 \\
\hline
\end{tabular}

Sources:

${ }^{\mathrm{a}}$ US Bureau of Economic Analysis

(http://www.bea.gov/newsreleases/regional/spi/2008/xls/spi0308.xls)

${ }^{\mathrm{b}}$ Carbon Monitoring for Action database (www.carma.org)

${ }^{\mathrm{c}}$ American Conservative Union, Ratings of Congress (http://www.acuratings.org/)

Table 2: Min and Max Values of Voting Determinants by Cloture Vote

\begin{tabular}{|c|c|c|c|c|c|c|}
\hline & \multicolumn{2}{|c|}{ Income } & \multicolumn{2}{c|}{ Fossil Fuel \% of Power } & \multicolumn{2}{c|}{ Conservative Rating } \\
\hline Vote & Min & Max & Min & Max & Min & Max \\
\hline No & $\$ 28,845$ & $\$ 43,226$ & 0.1051 & 0.9801 & 0 & 100 \\
\hline Yes & $\$ 29,537$ & $\$ 54,117$ & 0.0076 & 0.9845 & 0 & 92 \\
\hline
\end{tabular}


Table 3: Probit Regression Results

\begin{tabular}{|c|c|c|c|c|c|c|c|c|}
\hline & (1) & (2) & (3) & (4) & (5) & (6) & (7) & (8) \\
\hline Dependent Variable (Probability) & yes & yes & yes & yes & yes & yes & yes & yes \\
\hline$\%$ Correct Predictions & $93 \%$ & $93 \%$ & $86 \%$ & $90 \%$ & $93 \%$ & $90 \%$ & $92 \%$ & $93 \%$ \\
\hline $\begin{array}{l}\text { Income per Capita } \\
2007(\$ 10,000)\end{array}$ & $\begin{array}{l}0.136 \\
(2.02)^{*}\end{array}$ & $\begin{array}{l}0.135 \\
(2.01)^{\star}\end{array}$ & $\begin{array}{l}0.149 \\
(2.10)^{\star}\end{array}$ & $\begin{array}{l}0.140 \\
(2.03)^{\star}\end{array}$ & $\begin{array}{l}0.152 \\
(2.08)^{\star}\end{array}$ & $\begin{array}{l}0.145 \\
(2.04)^{\star}\end{array}$ & $\begin{array}{l}0.145 \\
(2.07)^{\star}\end{array}$ & $\begin{array}{l}0.155 \\
(2.00)^{\star}\end{array}$ \\
\hline $\begin{array}{l}\text { Fossil Fuel \% of Power } \\
2007\end{array}$ & $\begin{array}{l}-2.379 \\
(2.15)^{\star}\end{array}$ & $\begin{array}{l}-2.288 \\
(2.02)^{\star}\end{array}$ & $\begin{array}{l}-2.151 \\
(1.84)\end{array}$ & $\begin{array}{l}-2.512 \\
(2.14)^{\star}\end{array}$ & $\begin{array}{l}-2.466 \\
(2.06)^{\star}\end{array}$ & $\begin{array}{l}-2.520 \\
(2.15)^{\star}\end{array}$ & $\begin{array}{l}-2.429 \\
(2.14)^{*}\end{array}$ & $\begin{array}{l}-2.912 \\
(2.28)^{\star}\end{array}$ \\
\hline $\begin{array}{l}\text { ACU Conservative Rating } \\
2008\end{array}$ & $\begin{array}{l}-0.034 \\
(5.55)^{\star \star}\end{array}$ & $\begin{array}{l}-0.039 \\
(2.71)^{\star \star}\end{array}$ & $\begin{array}{l}-0.042 \\
(2.51)^{*}\end{array}$ & $\begin{array}{l}-0.034 \\
(5.52)^{\star \star}\end{array}$ & $\begin{array}{l}-0.038 \\
(5.16)^{\star \star}\end{array}$ & $\begin{array}{l}-0.038 \\
(5.17)^{\star \star}\end{array}$ & $\begin{array}{l}-0.034 \\
(5.55)^{\star \star}\end{array}$ & $\begin{array}{l}-0.036 \\
(4.90)^{\star \star}\end{array}$ \\
\hline Republican & & $\begin{array}{l}0.444 \\
(0.41)\end{array}$ & $\begin{array}{l}0.624 \\
(0.50)\end{array}$ & & & & & \\
\hline Female & & & $\begin{array}{l}0.981 \\
(1.45)\end{array}$ & & & & & \\
\hline \multicolumn{2}{|c|}{$\begin{array}{l}\text { FEMA [Disasters \& Emergencies] } \\
\text { (Droughts, Floods, Storms, Fires, Hurricanes) }\end{array}$} & & & $\begin{array}{l}0.035 \\
(0.41)\end{array}$ & & & & \\
\hline FEMA Hurricanes & & & & & $\begin{array}{l}0.156 \\
(1.20)\end{array}$ & $\begin{array}{l}0.159 \\
(1.28)\end{array}$ & & \\
\hline FEMA Fires & & & & & $\begin{array}{l}-0.359 \\
(0.59)\end{array}$ & & & \\
\hline FEMA Floods and Storms & & & & & $\begin{array}{l}-0.016 \\
(0.15)\end{array}$ & & & \\
\hline $\begin{array}{l}\text { Total Contributions From Electric } \\
\text { Utilities, Oil \& Gas, Coal Mines, } \\
\text { Transport, Transport Unions }\end{array}$ & & & & & & & $\begin{array}{l}0.068 \\
(0.57)\end{array}$ & \\
\hline Contributions from Electric Utilities & & & & & & & & $\begin{array}{l}-0.156 \\
(0.35)\end{array}$ \\
\hline Contributions from Oil \& Gas Com & & & & & & & & $\begin{array}{l}-0.024 \\
(0.06)\end{array}$ \\
\hline Contributions from Coal Mine Com & & & & & & & & $\begin{array}{l}1.398 \\
(1.17)\end{array}$ \\
\hline Constant & $\begin{array}{l}-1.513 \\
(0.64)\end{array}$ & $\begin{array}{l}-1.535 \\
(0.65)\end{array}$ & $\begin{array}{l}-2.239 \\
(0.88)\end{array}$ & $\begin{array}{l}-1.751 \\
(0.71)\end{array}$ & $\begin{array}{l}-2.082 \\
(0.79)\end{array}$ & $\begin{array}{l}-1.872 \\
(0.74)\end{array}$ & $\begin{array}{l}-1.957 \\
(0.78)\end{array}$ & $\begin{array}{l}-1.753 \\
(0.67)\end{array}$ \\
\hline Observations & 84 & 84 & 84 & 84 & 84 & 84 & 84 & 84 \\
\hline
\end{tabular}

Absolute value of $z$ statistics in parentheses

* significant at $5 \%$; ${ }^{* \star}$ significant at $1 \%$ 
Table 4: Model Prediction Accuracy

\begin{tabular}{|c|c|r|}
\hline Prediction & Frequency & \multicolumn{1}{c|}{$\%$} \\
\hline Correct & 78 & 92.9 \\
\hline Incorrect & 6 & 7.1 \\
\hline Total & 84 & 100.0 \\
\hline
\end{tabular}

Table 5. Incorrectly-Predicted Votes

\begin{tabular}{|c|c|c|l|l|}
\hline $\begin{array}{c}\text { Probability of } \\
\text { Yes Vote }\end{array}$ & $\begin{array}{c}\text { Predicted } \\
\text { Vote }\end{array}$ & $\begin{array}{c}\text { Actual } \\
\text { Vote }\end{array}$ & \multicolumn{1}{|c|}{ Senator } & \multicolumn{1}{|c|}{ State } \\
\hline 0.9788 & Yes & No & Johnson & South Dakota \\
\hline 0.8730 & Yes & No & Brown & Ohio \\
\hline 0.7172 & Yes & No & Dorgan & North Dakota \\
\hline 0.4542 & No & Yes & Rockefeller & West Virginia \\
\hline 0.2107 & No & Yes & Martinez & Florida \\
\hline 0.0623 & No & Yes & Dole & North Carolina \\
\hline
\end{tabular}

Table 6: Predicted Votes for Missing Senators

\begin{tabular}{|c|c|l|l|}
\hline $\begin{array}{c}\text { Probability of } \\
\text { Yes Vote }\end{array}$ & $\begin{array}{c}\text { Predicted } \\
\text { Vote }\end{array}$ & \multicolumn{1}{|c|}{ Senator } & \multicolumn{1}{|c|}{ State } \\
\hline 0.9999 & Yes & Clinton & New York \\
\hline 0.9997 & Yes & Kennedy & Massachusetts \\
\hline 0.9933 & Yes & Obama & Illinois \\
\hline 0.9850 & Yes & Biden & Delaware \\
\hline 0.8332 & Yes & Specter & Pennsylvania \\
\hline 0.7906 & Yes & Gregg & New Hampshire \\
\hline 0.7172 & Yes & Conrad & North Dakota \\
\hline 0.5919 & No & Coleman & Minnesota \\
\hline 0.5164 & No & Stevens & Alaska \\
\hline 0.4758 & No & Murkowski & Alaska \\
\hline 0.4542 & No & Byrd & West Virginia \\
\hline 0.2794 & No & Craig & Idaho \\
\hline 0.1170 & No & McCain & Arizona \\
\hline 0.0775 & No & Graham & South Carolina \\
\hline 0.0532 & No & Cornyn & Texas \\
\hline 0.0336 & No & DeMint & South Carolina \\
\hline
\end{tabular}


Table 7: Simulated Warner-Lieberman Votes

\begin{tabular}{|c|c|c|c|c|}
\hline \multicolumn{3}{|c|}{ State Indicators } & \multicolumn{2}{|c|}{ Projected Votes } \\
\hline $\begin{array}{l}\text { Per Capita } \\
\text { Income }\end{array}$ & $\begin{array}{l}\text { Fossil Fuel } \\
\% \text { of Power }\end{array}$ & $\begin{array}{c}\text { Conservative } \\
\text { Rating }\end{array}$ & $P($ Yes $)$ & Vote \\
\hline$\$ 29,000$ & 0 & 100 & 0.1653 & No \\
\hline$\$ 29,000$ & 0 & 30 & 0.9202 & Yes \\
\hline$\$ 29,000$ & 0 & 0 & 0.9924 & Yes \\
\hline$\$ 29,000$ & 0.69 & 100 & 0.0045 & No \\
\hline$\$ 29,000$ & 0.69 & 30 & 0.4070 & No \\
\hline$\$ 29,000$ & 0.69 & 0 & 0.7837 & Yes \\
\hline$\$ 29,000$ & 0.99 & 100 & 0.0004 & No \\
\hline$\$ 29,000$ & 0.99 & 30 & 0.1713 & No \\
\hline$\$ 29,000$ & 0.99 & 0 & 0.5282 & No \\
\hline$\$ 36,000$ & 0 & 100 & 0.4911 & No \\
\hline$\$ 36,000$ & 0 & 30 & 0.9908 & Yes \\
\hline$\$ 36,000$ & 0 & 0 & 0.9996 & Yes \\
\hline$\$ 36,000$ & 0.69 & 100 & 0.0481 & No \\
\hline$\$ 36,000$ & 0.69 & 30 & 0.7629 & Yes \\
\hline$\$ 36,000$ & 0.69 & 0 & 0.9587 & Yes \\
\hline$\$ 36,000$ & 0.99 & 100 & 0.0087 & No \\
\hline$\$ 36,000$ & 0.99 & 30 & 0.5007 & No \\
\hline$\$ 36,000$ & 0.99 & 0 & 0.8465 & Yes \\
\hline$\$ 54,000$ & 0 & 100 & 0.9923 & Yes \\
\hline$\$ 54,000$ & 0 & 30 & 1.0000 & Yes \\
\hline$\$ 54,000$ & 0 & 0 & 1.0000 & Yes \\
\hline$\$ 54,000$ & 0.69 & 100 & 0.7826 & Yes \\
\hline$\$ 54,000$ & 0.69 & 30 & 0.9992 & Yes \\
\hline$\$ 54,000$ & 0.69 & 0 & 1.0000 & Yes \\
\hline$\$ 54,000$ & 0.99 & 100 & 0.5268 & No \\
\hline$\$ 54,000$ & 0.99 & 30 & 0.9928 & Yes \\
\hline$\$ 54,000$ & 0.99 & 0 & 0.9997 & Yes \\
\hline
\end{tabular}

Table 8: Impact of State Income Per Capita Yes-Vote Probabilities For 27 Simulations

\begin{tabular}{|c|r|r|r|r|r|}
\hline & \multicolumn{5}{|c|}{ Probability of Yes Vote } \\
\hline $\begin{array}{l}\text { Per Capita } \\
\text { Income }\end{array}$ & Minimum & Quartile 1 & Median & Quartile 3 & Maximum \\
\hline$\$ 29,000$ & 0.00 & 0.17 & 0.41 & 0.78 & 0.99 \\
\hline$\$ 36,000$ & 0.01 & 0.49 & 0.76 & 0.96 & 1.00 \\
\hline$\$ 54,000$ & 0.53 & 0.99 & 1.00 & 1.00 & 1.00 \\
\hline
\end{tabular}


Table 9: Projected Warner-Lieberman Votes

\begin{tabular}{|l|r|r|r|}
\hline $\begin{array}{l}\text { Minimum } \\
\text { State Income }\end{array}$ & \multicolumn{3}{|c|}{$\begin{array}{r}\text { Projected Cloture } \\
\text { Vote }\end{array}$} \\
\hline & No & Yes & Total \\
\hline $\begin{array}{l}\$ 29,000 \\
\text { (Current) }\end{array}$ & 45 & 55 & 100 \\
\hline$\$ 34,000$ & 43 & 57 & 100 \\
\hline$\$ 39,000$ & 40 & 60 & 100 \\
\hline$\$ 44,000$ & 32 & 68 & 100 \\
\hline$\$ 49,000$ & 7 & 93 & 100 \\
\hline$\$ 54,000$ & 0 & 100 & 100 \\
\hline
\end{tabular}


Table 10: Projected Impacts of Warner-Lieberman (EIA, 2008)

\begin{tabular}{|l|r|r|r|r|}
\hline & & \multicolumn{3}{|c|}{ Family Income Range } \\
\hline & & $\begin{array}{c}\$ 0- \\
\$ 9,999\end{array}$ & $\begin{array}{c}\$ 10,000- \\
\$ 29,999\end{array}$ & $\begin{array}{c}\$ 30,000 \\
\$ 49,999\end{array}$ \\
\hline Midpoint Income & & $\$ 5,000$ & $\$ 20,000$ & $\$ 40,000$ \\
\hline Household Spending & & & & \\
\hline Energy & & 1,039 & 1,260 & 1,456 \\
\hline Transport & & 839 & 1,046 & 1,566 \\
\hline Total & & 1,878 & 2,306 & 3,022 \\
\hline Income Share & & 0.3756 & 0.115313 & 0.07555 \\
\hline & & & & \\
\hline Cost Increase & & & & \\
\hline Energy & $5 \%$ & 51.9 & 63.0 & 72.8 \\
\hline Low & $27 \%$ & 280.5 & 340.2 & 393.1 \\
\hline High & & & & \\
\hline Transport & $9 \%$ & 75.5 & 94.2 & 140.9 \\
\hline Low & $21 \%$ & 176.2 & 219.7 & 328.9 \\
\hline High & & & & \\
\hline Projected Cost Increases & & 127.46 & 157.16 & 213.74 \\
\hline Low Increase & & $37.5 \%$ & $9.2 \%$ & $4.5 \%$ \\
\hline High Increase & & $30.9 \%$ & $7.2 \%$ & $3.2 \%$ \\
\hline$\%$ Cost Increases & & & & \\
\hline Low Increase & & $6.79 \%$ & $6.81 \%$ & $7.07 \%$ \\
\hline High Increase & & $24.32 \%$ & $24.28 \%$ & $23.89 \%$ \\
\hline & & & & \\
\hline Total Revenue (\$Billion) & 150 & & & \\
\hline Population (Million) & 300 & & & \\
\hline & & & & \\
\hline Family Payment & & & & \\
\hline Percent Allocated & & & & \\
\hline Family Size & & & & \\
\hline & & & & \\
\hline Net Gain & & & & \\
\hline Low Increase & & & & \\
\hline High Increase & & & & \\
\hline & & & & \\
\hline Income Increase & & & & \\
\hline Low Increase & & & & \\
\hline High Increase & & & & \\
\hline
\end{tabular}




\section{Appendix A \\ Correctly-Predicted Votes}

\begin{tabular}{|c|c|c|c|c|c|}
\hline \multicolumn{3}{|c|}{ Correctly-Predicted Yes Votes } & \multicolumn{3}{|c|}{ Correctly-Predicted No Votes } \\
\hline State & Senator & $\mathrm{P}($ Yes $)$ & State & Senator & $\mathrm{P}($ Yes $)$ \\
\hline Connecticut & Dodd & 1.0000 & Louisiana & Landrieu & 0.5627 \\
\hline Connecticut & Lieberman & 1.0000 & Ohio & Voinovich & 0.3117 \\
\hline New Jersey & Lautenberg & 1.0000 & Idaho & Crapo & 0.3027 \\
\hline New Jersey & Menendez & 1.0000 & Nebraska & Hagel & 0.2034 \\
\hline New York & Schumer & 0.9999 & Nevada & Ensign & 0.2012 \\
\hline Washington & Murray & 0.9999 & South Dakota & Thune & 0.1679 \\
\hline Washington & Cantwell & 0.9998 & Tennessee & Alexander & 0.1586 \\
\hline Vermont & Leahy & 0.9997 & Wyoming & Enzi & 0.1081 \\
\hline Vermont & Sanders & 0.9995 & Tennessee & Corker & 0.1079 \\
\hline Massachusetts & Kerry & 0.9994 & Indiana & Lugar & 0.1065 \\
\hline Maryland & Mikulski & 0.9992 & Texas & Hutchison & 0.0897 \\
\hline Maryland & Cardin & 0.9992 & Colorado & Allard & 0.0860 \\
\hline California & Feinstein & 0.9987 & Wyoming & Barrasso & 0.0849 \\
\hline California & Boxer & 0.9980 & Alabama & Sessions & 0.0766 \\
\hline Illinois & Durbin & 0.9967 & Kansas & Roberts & 0.0678 \\
\hline Oregon & Wyden & 0.9938 & North Carolina & Burr & 0.0623 \\
\hline Minnesota & Klobuchar & 0.9885 & lowa & Grassley & 0.0595 \\
\hline Nevada & Reid & 0.9880 & Kansas & Brownback & 0.0555 \\
\hline Virginia & Webb & 0.9853 & Alabama & Shelby & 0.0550 \\
\hline Rhode Island & Reed & 0.9852 & Georgia & Chambliss & 0.0510 \\
\hline Rhode Island & Whitehouse & 0.9852 & Louisiana & Vitter & 0.0404 \\
\hline Pennsylvania & Casey & 0.9800 & Missouri & Bond & 0.0387 \\
\hline Hawaii & Akaka & 0.9713 & Georgia & Isakson & 0.0383 \\
\hline Hawaii & Inouye & 0.9713 & Arizona & Kyl & 0.0308 \\
\hline Delaware & Carper & 0.9711 & Mississippi & Cochran & 0.0186 \\
\hline Florida & Nelson & 0.9624 & Mississippi & Wicker & 0.0164 \\
\hline Colorado & Salazar & 0.9480 & Utah & Bennett & 0.0159 \\
\hline Wisconsin & Kohl & 0.9457 & Utah & Hatch & 0.0146 \\
\hline Michigan & Levin & 0.9332 & New Mexico & Domenici & 0.0137 \\
\hline Wisconsin & Feingold & 0.9290 & Oklahoma & Inhofe & 0.0095 \\
\hline Michigan & Stabenow & 0.9137 & Oklahoma & Coburn & 0.0095 \\
\hline lowa & Harkin & 0.8473 & Kentucky & Bunning & 0.0035 \\
\hline Oregon & Smith & 0.8429 & Kentucky & McConnell & 0.0035 \\
\hline Maine & Snowe & 0.8266 & & & \\
\hline Montana & Tester & 0.8115 & & & \\
\hline Arkansas & Lincoln & 0.8059 & & & \\
\hline Arkansas & Pryor & 0.7867 & & & \\
\hline Missouri & McCaskill & 0.7832 & & & \\
\hline Nebraska & Nelson & 0.7788 & & & \\
\hline Montana & Baucus & 0.7726 & & & \\
\hline Virginia & Warner & 0.7521 & & & \\
\hline Maine & Collins & 0.7483 & & & \\
\hline New Hampshire & Sununu & 0.6556 & & & \\
\hline Indiana & Bayh & 0.6504 & & & \\
\hline New Mexico & Bingaman & 0.6347 & & & \\
\hline
\end{tabular}


Appendix B

State and Senator Data

\begin{tabular}{|c|c|c|c|c|c|c|c|c|c|c|c|c|c|c|}
\hline State & $\begin{array}{c}\text { Per } \\
\text { Capita } \\
\text { Income }\end{array}$ & $\begin{array}{l}\text { Fossil } \\
\text { Fuel } \\
\text { Percent }\end{array}$ & Senator & $\begin{array}{c}\text { ACU } \\
\text { Rating }\end{array}$ & Party & Gender & P(Yes) & Vote & Senator & $\begin{array}{l}\text { ACU } \\
\text { Rating }\end{array}$ & Party & Gender & $P($ Yes $)$ & Vote \\
\hline Alabama & $\$ 32,404$ & 0.6286 & Sessions & 83 & $\mathrm{R}$ & $M$ & 0.0766 & No & Shelby & 88 & $\mathrm{R}$ & $M$ & 0.0550 & No \\
\hline Alaska & $\$ 40,352$ & 0.7361 & Stevens & 64 & $\mathrm{R}$ & $M$ & 0.5164 & Missing & Murkowski & 67 & $\mathrm{R}$ & $\mathrm{F}$ & 0.4758 & Missing \\
\hline Arizona & $\$ 33,029$ & 0.6069 & McCain & 80 & $\mathrm{R}$ & $M$ & 0.1170 & Missing & Kyl & 100 & $\mathrm{R}$ & $M$ & 0.0308 & No \\
\hline Arkansas & $\$ 30,060$ & 0.5747 & Lincoln & 10 & $\mathrm{D}$ & $\mathrm{F}$ & 0.8059 & Yes & Pryor & 12 & $\mathrm{D}$ & $M$ & 0.7867 & Yes \\
\hline California & $\$ 41,571$ & 0.4733 & Feinstein & 0 & $\mathrm{D}$ & $\mathrm{F}$ & 0.9987 & Yes & Boxer & 4 & $\mathrm{D}$ & $\mathrm{F}$ & 0.9980 & Yes \\
\hline Colorado & $\$ 41,042$ & 0.9096 & Salazar & 8 & $D$ & $M$ & 0.9480 & Yes & Allard & 96 & $\mathrm{R}$ & $M$ & 0.0860 & No \\
\hline Connecticut & $\$ 54,117$ & 0.4208 & Dodd & 0 & $\mathrm{D}$ & $M$ & 1.0000 & Yes & Lieberman & 8 & 1 & $M$ & 1.0000 & Yes \\
\hline Delaware & $\$ 40,608$ & 0.7706 & Biden & 0 & $\mathrm{D}$ & $M$ & 0.9850 & Missing & Carper & 8 & $D$ & M & 0.9711 & Yes \\
\hline Florida & $\$ 38,444$ & 0.7538 & Nelson & 4 & $\mathrm{D}$ & $M$ & 0.9624 & Yes & Martinez & 80 & $\mathrm{R}$ & $M$ & 0.2107 & Yes \\
\hline Georgia & $\$ 33,457$ & 0.6470 & Chambliss & 92 & $\mathrm{R}$ & $M$ & 0.0510 & No & Isakson & 96 & $\mathrm{R}$ & $M$ & 0.0383 & No \\
\hline Hawaii & $\$ 39,239$ & 0.8057 & Akaka & 0 & $D$ & $M$ & 0.9713 & Yes & Inouye & 0 & $D$ & M & 0.9713 & Yes \\
\hline Idaho & $\$ 31,197$ & 0.1051 & Crapo & 88 & $\mathrm{R}$ & $M$ & 0.3027 & No & Craig & 90 & $\mathrm{R}$ & $M$ & 0.2794 & Missing \\
\hline Illinois & $\$ 40,322$ & 0.5264 & Durbin & 0 & $\mathrm{D}$ & $M$ & 0.9967 & Yes & Obama & 7 & $\mathrm{D}$ & $M$ & 0.9933 & Missing \\
\hline Indiana & $\$ 33,616$ & 0.9494 & Bayh & 12 & $D$ & $\mathrm{M}$ & 0.6504 & Yes & Lugar & 60 & $\mathrm{R}$ & $M$ & 0.1065 & No \\
\hline lowa & $\$ 35,023$ & 0.8186 & Harkin & 8 & $\mathrm{D}$ & $M$ & 0.8473 & Yes & Grassley & 84 & $\mathrm{R}$ & $M$ & 0.0595 & No \\
\hline Kansas & $\$ 36,768$ & 0.7759 & Roberts & 92 & $\mathrm{R}$ & $M$ & 0.0678 & No & Brownback & 95 & $\mathrm{R}$ & $M$ & 0.0555 & No \\
\hline Kentucky & $\$ 31,111$ & 0.9595 & McConnell & 92 & $\mathrm{R}$ & $M$ & 0.0035 & No & Bunning & 92 & $\mathrm{R}$ & $M$ & 0.0035 & No \\
\hline Louisiana & $\$ 34,756$ & 0.7105 & Landrieu & 40 & $\mathrm{D}$ & $\mathrm{F}$ & 0.5627 & No & Vitter & 96 & $\mathrm{R}$ & $M$ & 0.0404 & No \\
\hline Maine & $\$ 33,722$ & 0.4938 & Snowe & 28 & $\mathrm{R}$ & $\mathrm{F}$ & 0.8266 & Yes & Collins & 36 & $\mathrm{R}$ & $\mathrm{F}$ & 0.7483 & Yes \\
\hline Maryland & $\$ 46,021$ & 0.6601 & Cardin & 0 & $\mathrm{D}$ & $M$ & 0.9992 & Yes & Mikulski & 0 & $D$ & $\mathrm{~F}$ & 0.9992 & Yes \\
\hline Massachusetts & $\$ 49,082$ & 0.7376 & Kennedy & 0 & $\mathrm{D}$ & $M$ & 0.9997 & Missing & Kerry & 4 & $\mathrm{D}$ & $M$ & 0.9994 & Yes \\
\hline Michigan & $\$ 35,086$ & 0.6796 & Levin & 4 & $\mathrm{D}$ & $M$ & 0.9332 & Yes & Stabenow & 8 & $\mathrm{D}$ & $\mathrm{F}$ & 0.9137 & Yes \\
\hline Minnesota & $\$ 41,034$ & 0.6947 & Klobuchar & 4 & $\mathrm{D}$ & $\mathrm{F}$ & 0.9885 & Yes & Coleman & 64 & $\mathrm{R}$ & $M$ & 0.5919 & Missing \\
\hline Mississippi & $\$ 28,845$ & 0.7011 & Cochran & 83 & $\mathrm{R}$ & $M$ & 0.0186 & No & Wicker & 84.5 & $\mathrm{R}$ & M & 0.0164 & No \\
\hline Missouri & $\$ 34,389$ & 0.8840 & McCaskill & 8 & $D$ & $\mathrm{~F}$ & 0.7832 & Yes & Bond & 83 & $\mathrm{R}$ & $M$ & 0.0387 & No \\
\hline Montana & $\$ 32,458$ & 0.6173 & Tester & 16 & $\mathrm{D}$ & $M$ & 0.8115 & Yes & Baucus & 20 & $\mathrm{D}$ & $M$ & 0.7726 & Yes \\
\hline Nebraska & $\$ 36,471$ & 0.6662 & Nelson & 32 & $\mathrm{D}$ & $M$ & 0.7788 & Yes & Hagel & 79 & $\mathrm{R}$ & M & 0.2034 & No \\
\hline Nevada & $\$ 40,480$ & 0.7269 & Reid & 0 & $\mathrm{D}$ & $M$ & 0.9880 & Yes & Ensign & 91 & $\mathrm{R}$ & $M$ & 0.2012 & No \\
\hline New Hampshire & $\$ 41,512$ & 0.3656 & Gregg & 72 & $\mathrm{R}$ & $M$ & 0.7906 & Missing & Sununu & 84 & $\mathrm{R}$ & $M$ & 0.6556 & Yes \\
\hline New Jersey & $\$ 49,194$ & 0.4402 & Lautenberg & 0 & $D$ & $M$ & 1.0000 & Yes & Menendez & 0 & $D$ & $M$ & 1.0000 & Yes \\
\hline
\end{tabular}




\begin{tabular}{|c|c|c|c|c|c|c|c|c|c|c|c|c|c|c|}
\hline State & $\begin{array}{c}\text { Per } \\
\text { Capita } \\
\text { Income }\end{array}$ & $\begin{array}{l}\text { Fossil } \\
\text { Fuel } \\
\text { Percent }\end{array}$ & Senator & $\begin{array}{c}\text { ACU } \\
\text { Rating }\end{array}$ & Party & Gender & $P($ Yes $)$ & Vote & Senator & $\begin{array}{c}\text { ACU } \\
\text { Rating }\end{array}$ & Party & Gender & $P($ Yes $)$ & Vote \\
\hline New Mexico & $\$ 31,474$ & 0.9591 & Bingaman & 4 & $\mathrm{D}$ & $M$ & 0.6347 & Yes & Domenici & 79 & $\mathrm{R}$ & M & 0.0137 & No \\
\hline North Carolina & $\$ 33,636$ & 0.6156 & Dole & 92 & $\mathrm{R}$ & $\mathrm{F}$ & 0.0623 & Yes & Burr & 92 & $\mathrm{R}$ & $M$ & 0.0623 & No \\
\hline North Dakota & $\$ 34,846$ & 0.9406 & Conrad & 12 & $\mathrm{D}$ & $M$ & 0.7172 & Missing & Dorgan & 12 & $\mathrm{D}$ & M & 0.7172 & No \\
\hline Ohio & $\$ 34,874$ & 0.8757 & Brown & 0 & $\mathrm{D}$ & $M$ & 0.8730 & No & Voinovich & 48 & $\mathrm{R}$ & $M$ & 0.3117 & No \\
\hline Oklahoma & $\$ 34,153$ & 0.8706 & Coburn & 100 & $\mathrm{R}$ & $M$ & 0.0095 & No & Inhofe & 100 & $\mathrm{R}$ & M & 0.0095 & No \\
\hline Oregon & $\$ 34,784$ & 0.2411 & Wyden & 4 & $\mathrm{D}$ & $M$ & 0.9938 & Yes & Smith & 48 & $\mathrm{R}$ & $M$ & 0.8429 & Yes \\
\hline Pennsylvania & $\$ 38,788$ & 0.6007 & Casey & 8 & $\mathrm{D}$ & $M$ & 0.9800 & Yes & Specter & 40 & $\mathrm{R}$ & $M$ & 0.8332 & Missing \\
\hline Rhode Island & $\$ 39,463$ & 0.7023 & Reed & 0 & $\mathrm{D}$ & $M$ & 0.9852 & Yes & Whitehouse & 0 & $\mathrm{D}$ & $M$ & 0.9852 & Yes \\
\hline South Carolina & $\$ 31,013$ & 0.4752 & Graham & 88 & $\mathrm{R}$ & $M$ & 0.0775 & Missing & DeMint & 100 & $\mathrm{R}$ & $M$ & 0.0336 & Missing \\
\hline South Dakota & $\$ 33,905$ & 0.4470 & Johnson & 0 & $\mathrm{D}$ & $M$ & 0.9788 & No & Thune & 88 & $\mathrm{R}$ & $M$ & 0.1679 & No \\
\hline Tennessee & $\$ 33,280$ & 0.5986 & Alexander & 76 & $\mathrm{R}$ & $M$ & 0.1586 & No & Corker & 83 & $\mathrm{R}$ & M & 0.1079 & No \\
\hline Texas & $\$ 37,187$ & 0.7942 & Hutchison & 88 & $\mathrm{R}$ & $\mathrm{F}$ & 0.0897 & No & Cornyn & 96 & $\mathrm{R}$ & $M$ & 0.0532 & Missing \\
\hline Utah & $\$ 31,189$ & 0.9756 & Bennett & 75 & $\mathrm{R}$ & M & 0.0159 & No & Hatch & 76 & $\mathrm{R}$ & M & 0.0146 & No \\
\hline Vermont & $\$ 36,670$ & 0.0076 & Leahy & 0 & $D$ & $M$ & 0.9997 & Yes & Sanders & 4 & 1 & $M$ & 0.9995 & Yes \\
\hline Virginia & $\$ 41,347$ & 0.5811 & Webb & 16 & $\mathrm{D}$ & $M$ & 0.9853 & Yes & Warner & 60 & $\mathrm{R}$ & $M$ & 0.7521 & Yes \\
\hline Washington & $\$ 40,414$ & 0.1475 & Murray & 0 & $\mathrm{D}$ & $\mathrm{F}$ & 0.9999 & Yes & Cantwell & 4 & $\mathrm{D}$ & $\mathrm{F}$ & 0.9998 & Yes \\
\hline West Virginia & $\$ 29,537$ & 0.9845 & Byrd & 8 & $\mathrm{D}$ & $M$ & 0.4542 & Missing & Rockefeller & 8 & $\mathrm{D}$ & M & 0.4542 & Yes \\
\hline Wisconsin & $\$ 36,047$ & 0.7478 & Kohl & 0 & $\mathrm{D}$ & $M$ & 0.9457 & Yes & Feingold & 4 & $\mathrm{D}$ & M & 0.9290 & Yes \\
\hline Wyoming & $\$ 43,226$ & 0.9801 & Enzi & 96 & $\mathrm{R}$ & $M$ & 0.1081 & No & Barrasso & 100 & $\mathrm{R}$ & $M$ & 0.0849 & No \\
\hline
\end{tabular}




\section{Appendix C}

Model Certified Atmospheric Share (CASH) Certificate

Payable From United States Carbon Account Proceeds (USCAP)

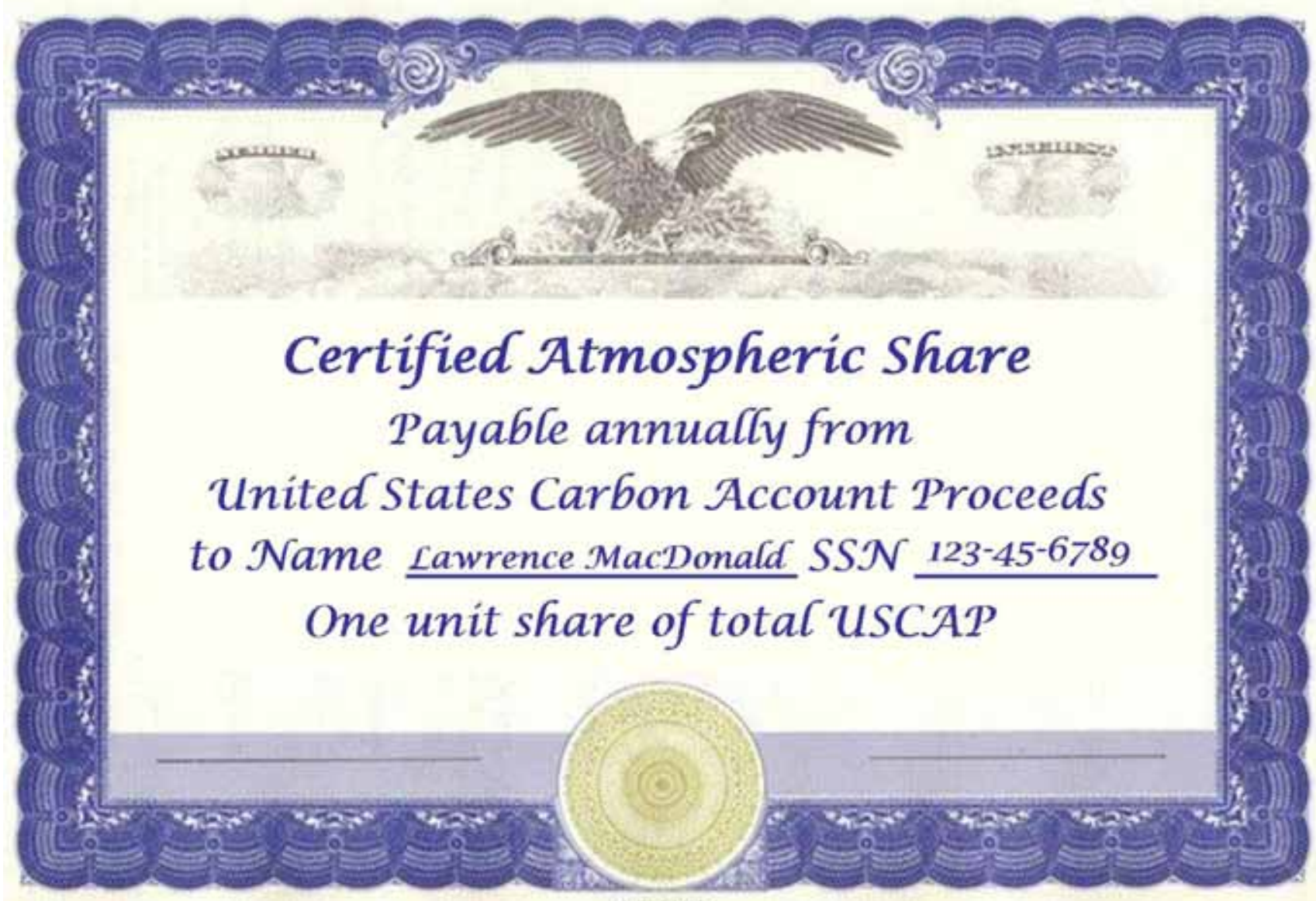

isencruenom

Background graphic image source: www.corpkit.com 